\title{
REMEDIATION OF THE AREAS CONTAMINATED BY DEPLETED URANIUM AMMUNITION
}

\author{
Dejan R. Inđić \\ University of Defence in Belgrade, Military Academy, \\ Department of Tactics, Belgrade, Republic of Serbia, \\ e-mail: indjicrdejan@gmail.rs, \\ ORCID iD: (Dhttps://orcid.org/0000-0001-9111-0472
}

DOI: 10.5937/vojtehg69-28844; https://doi.org/10.5937/vojtehg69-28844

\author{
FIELD: Chemical technology \\ ARTICLE TYPE: Professional paper
}

\begin{abstract}
:
Introduction/purpose: The consequences of the NATO aggression on the Republic of Serbia (then part of FR Yugoslavia) in 1999 are still being considered, especially from the aspect of the use of illicit means such as cluster and graphite bombs, depleted uranium ammunition (DUA), etc. There is no doubt that the use of depleted uranium, as a type of weapon of mass destruction (radiological weapon) is mostly in the focus of public interest. The amount of DUA used and the consequences of its use have not yet been fully proven (even after 20 years), but it can be said with certainty that it has caused certain side effects. The units of the Yugoslav Army at that time were mostly the target of this type of ammunition and certainly suffered the greatest consequences. However, DUA also targeted infrastructure facilities, base stations, television transmitters, and agricultural land.

Methods: Special scientific methods (mainly analysis and synthesis methods) and empirical methods (content analysis method and observation method) were used in the paper.

Results: The consequences of the effect of DUA on people, material goods, and environmental degradation are considered as well as the directions of further work in this area.

Conclusion: The paper presents the results of the radiological reconnaissance and radiological decontamination of the contaminated $D U A$ areas, which were carried out by $A B H$ service units (then $A B H O$ ) with the help of other branches and services of the Serbian Army, as well as the institutions of the Republic of Serbia (INS „Vinča“, MMA, etc.).
\end{abstract}

Key words: uranium, depleted uranium ammunition, $A B H$ service, reconnaissance, decontamination. 


\section{Introduction}

Uranium-238 $\left({ }^{238} \mathrm{U}\right.$ or $\left.\mathrm{U}-238\right)$ is the most common uranium isotope that can be found in nature (about $99.3 \%$ of the mass of natural uranium is uranium-238). Unlike uranium-235, it is not subject to fission, which means that it cannot sustain a chain reaction. However, it is flexible for fast neutrons and fertile, which means that it can be converted into fission plutonium-239. The half-life of this element is $1.41 \times 1017$ seconds (4.468 $\times 109$ years, i.e. $\sim 4.5$ billion years). Due to its distribution in nature and half-life in relation to other radioactive elements, uranium-238 produces $\sim 40 \%$ of the radioactive heat produced inside the Earth. (Arevalo et al, 2009, pp.361-369)

Depleted uranium is a toxic by-product of the natural uranium enrichment process and is highly hazardous radioactive waste. It was stored until the beginning of the seventies of the last century, after which it began to be used for the production of projectile penetrators. This is the main reason for the public attention this type of weapon has gained in the last thirty years, starting from its first official use in 1991 in Iraq, and then through the Republic of Srpska (RS/BiH), the Republic of Serbia, Libya and others countries. It is certainly necessary to state that this type of radiological weapon indiscriminately, inhumanely and insidiously causes consequences for both the winners and the losers. (Rajković, 2001, pp.167-182)

The harmful effects of depleted uranium have been known to a narrow circle of experts in the United States for a very long time. It is estimated that in the United States alone, close to 900,000 people were exposed to the harmful effects of depleted uranium between 1945 and 1995 (uranium miners, their families, laboratory workers in Los Alamos and Oak Ridge, residents of the regions around nuclear power plants, residents of the Marshall Islands, members of the U.S. military, etc.).

During the NATO aggression on FR Yugoslavia, thousands of depleted uranium projectiles were fired from A-10 Thunderbolt II aircraft targeting army units as well as certain facilities.

According to NATO data, this ammunition was fired at: 84 locations on the territory of Kosovo and Metohija (KiM), 10 locations on the territory of the Republic of Serbia and 1 location on the territory of the Republic of Montenegro with a total of 112 DUA strikes. Data from the then Yugoslav Army (YA) show: 85 locations on the territory of Kosovo and Metohija, 4 locations on the territory of the Republic of Serbia and 1 location on the territory of the Republic of Montenegro with a total of 99 DUA strikes. 
From the above we can conclude that there are different data on the use of DUA in the area of the Republic of Serbia, but certainly the data of the YA (now the Serbian Army) must be taken as valid, because they were verified in the field (by conducting radiological surveys of the affected areas).

Immediately after DUA strikes and after a certain period of time, army units (mainly $\mathrm{ABH}$ services) performed radiological (R) reconnaissance of the contaminated areas. After reviewing the consequences, preparations were made for the subsequent elimination of the consequences of the application of DUA with a focus on radiological decontamination.

The paper aims to show the way of realization of these tasks, the problems that the Army units encountered, but also to highlight the successes that have been achieved in the remediation of the areas contaminated with DUA. The Serbian Army (YA, AS, and MN) is the first to completely remediate the consequences of the use of DUA in the world, especially in the segment of radiological decontamination. (Inđić \& Filipović, 2018, pp.259-281)

\section{Basic characteristics of depleted uranium}

As already mentioned, uranium ( $U$, lat. Uranium) is a chemical element from the group A actinoids of group III B. Among the elements that occur naturally on Earth, it has the largest atomic number a (92) and it is weakly radioactive. Natural uranium occurs in the form of 3 isotopes: ${ }^{238} \mathrm{U}(99.284 \%),{ }^{235} \mathrm{U}(0.711 \%)$ and slightly ${ }^{234} \mathrm{U}(0.0058 \%)$. The isotope ${ }^{235} \mathrm{U}$ undergoes spontaneous nuclear separation under the influence of thermal neutrons. The isotope ${ }^{238} \mathrm{U}$ receives neutrons, as a result of which it is converted into ${ }^{239} \mathrm{Pu}$ (plutonium). Also, the artificial isotope ${ }^{233} \mathrm{U}$ separates the nucleus, and is obtained by bombarding ${ }^{232}$ torium with neutrons. (Meija et al, 2016, pp.265-291)

Uranium is a relatively soft, silvery-light metal of high density. It occurs in three allotropic modifications, Table 1 (Binder, 1999, pp.674682).

Powdered uranium is self-igniting. Most acids dissolve uranium in a metallic form, while bases do not "attack" it. On exposure to air, a layer of oxide is formed on the surface of uranium metal, which protects it from further oxidation. (Brauer, 1975, p.1195)

Uranium builds a whole series of compounds in which it can be in states from +2 to +6 . The color of the uranium complex, as a rule, strongly depends on the oxidation number, but also on the ligand in the 
environment. The following combinations of color and oxidation state most often occur in aqueous solutions, as well as in solid compounds: $\mathrm{U}^{3+}$ (purple), $\mathrm{U}^{4+}$ (green), $\mathrm{U}^{\mathrm{V}} \mathrm{O}_{2}{ }^{+}$(pink), and $\mathrm{U}^{\mathrm{V} \mathrm{O}} \mathrm{O}_{2}{ }^{2+}$ (yellow). (Holleman et al, 2007)

Table 1 - Modifications of uranium at atmospheric pressure

Таблица 1 - Модификации урана при атмосфрерном давлении

Табела 1 - Модификације уранијума при атмосфрерском притиску

\begin{tabular}{|l|l|l|}
\hline Phase & $\begin{array}{l}\text { Stable } \\
\text { temperature range }\end{array}$ & Crystal system \\
\hline$\alpha$ - uranium & to the $688{ }^{\circ} \mathrm{C}$ & $\begin{array}{l}\text { orthorhombic }(\mathrm{a}=285.4 \mathrm{pm}, \mathrm{b}=586.9 \mathrm{pm}, \\
\mathrm{c}=495.6 \mathrm{pm})\end{array}$ \\
\hline$\beta$ - uranium & $\begin{array}{l}\text { between } 688^{\circ} \mathrm{C} \text { and } \\
776{ }^{\circ} \mathrm{C}\end{array}$ & $\begin{array}{l}\text { tetragonal }(\mathrm{a}=1075.9 \mathrm{pm}, \\
\mathrm{C}=565.6 \mathrm{pm})\end{array}$ \\
\hline Y- uranium & above $776{ }^{\circ} \mathrm{C}$ & cubic $(\mathrm{a}=352.5 \mathrm{pm})$ \\
\hline
\end{tabular}

Uranium is present in the form of chemical compounds in the amount of $2.4 \mathrm{ppm}$ in the nature. It can be found in rocks, water, plants, animals, and even in the human body. It also occurs in larger quantities in minerals, the most important of which are:

- uranium $\mathrm{U}_{3} \mathrm{O}_{8}$ and

- $\mathrm{K}_{2}\left(\mathrm{UO}_{2}\right)_{2}\left(\mathrm{VO}_{4}\right)_{2} \cdot 2 \mathrm{H}_{2} \mathrm{O}$.

Uranium is an extremely toxic element, very similar to mercury and arsenic. The degree of toxicity depends on the chemical composition and solubility of the compound it forms. Toxicity depends, among other things, on their solubility. Easily soluble salts of uranium are the most toxic, while sparingly soluble oxides are less toxic. Uranium is teratogenic, i.e. causes deformities and / or damage to the fetus in the womb. The most toxic are compounds in which uranium is hexavalent. Uranium is at the same time a radioactive element, so that it has a harmful effect on the organism by alpha-gamma emission.

Humans can be contaminated with uranium during all phases of exploitation, processing and use in several ways:

- by inhalation (via the respiratory system),

- ingestion (via food and water, through the digestive system), and

- through the skin, both healthy and damaged (wound) or diseased.

Regardless of the route of contamination, the ingested uranium binds to proteins, bicarbonates and erythrocyte membranes (red blood cells) in the blood. Only an hour later, $95 \%$ of the matured uranium 
disappears from the blood, out of which over $50 \%$ is excreted through the kidneys and urinary tract. The remaining uranium is deposited in the body. As we can see, the most important way to eliminate uranium from the body is through the kidneys and urinary tract.

Depleted uranium concentrations can be determined by several methods:

1. gamma spectrometric method,

2. alpha spectrometry,

3. alpha radiometry,

4. atomic absorption spectrometry, with a flame detector, and

5. neutron activation analysis using gamma spectrometry.

All methods except the gamma spectrometric analysis require a very complicated sample preparation or are very expensive. The gamma spectrometric analysis enables a very simple sample preparation which requires only its homogenization. This method can be used to analyze all types of samples: soil, vegetation, water, air, food, and urine. The sensitivity of the method is $80 \mu \mathrm{g}$. (Đurić \& Popović, 2000, pp.50-52)

If an increased degree of radioactive contamination (above 0.5 $\mu \mathrm{Gy} / \mathrm{h}$ ) has been determined in a certain area, the area should be marked with a contaminated soil marking kit (CSM kit) or hand tools and samples should be taken for analysis. Samples are taken from the place where the greatest contamination was determined and from the place of the outer borders of the marked contaminated area, i.e. from 3 to 5 places. All samples should weigh about $1.5 \mathrm{~kg}$. Sampling is realized as follows:

1. Soil - it is necessary to take two samples, individual masses of about $1.5 \mathrm{~kg}$ :

Sample I: the surface layer of vegetation or soil with an area of $1 \mathrm{~m}^{2}$.

Sample II: another sample of the soil layer is taken from the same surface to a depth of $2 \mathrm{~cm}$. (Serbian Armed Forces - General Staff, 2000, pp.14-15)

2. Water - it is necessary to take $40 \mathrm{I}$ of previously turbid water.

3. Air sample is taken by special devices (e.g. chemical detectors), through a cellulose-asbestos filter (the sample is the filter itself). The aerosol sample is taken as soon as possible and as close as possible to the place of explosion, and it can be taken later in the period of up to 2 weeks from the moment of strike.

4. Food sample of plant and animal origin is taken in the amount of about $1.5 \mathrm{~kg}$, taking into account the volume. 
5. Urine - the exposed person collects a 24-hour urine sample in a special container.

6. Parts of the projectile - due to the large specific weight of the material from which the projectile was made and the required geometry of measurement, it is necessary to take several smaller pieces, with a total weight of about $1.5 \mathrm{~kg}$.

All samples should be:

- packed in PVC bags or containers (which have been checked for contamination),

- closed and marked well (date and place of the sampling, date of strike, quantity, who took the sample, etc.), and

- submitted to the competent institution for analysis, with the necessary supporting documentation which is adequately completed.

The main application of uranium is the use of its ${ }^{235} \mathrm{U}$ isotopes as a material for the production of nuclear bombs, nuclear reactors in nuclear power plants, as well as for the launch of submarines.

Other applications of uranium:

- used for painting ceramics, but no longer used due to its radiation;

- ${ }^{238} \mathrm{U}$ is converted to plutonium in atomic reactors;

- uranium metal is used as a shield in X-ray generators due to its large atomic mass;

- also used in photography and chemical analyses.

Natural uranium has three isotopes $\left({ }^{234} U(0.006 \%),{ }^{235} U(0.71 \%)\right.$, and ${ }^{238} \mathrm{U}(99.28 \%)$ ) but only ${ }^{235} \mathrm{U}$ (as a natural nuclear fuel) is important for nuclear energy, while its content does not fall below 0.2-0.3\%. When this happens, it is called depleted uranium ${ }^{235} \mathrm{U}$ (depleted as a nuclear fuel, but not harmless from the aspect of protecting the human population). It occurs most often:

- as a by-product of the process of enrichment of natural uranium for the needs of nuclear reactors and nuclear weapons $\left({ }^{238} U\right)$ and

- when extracting plutonium from the spent fuel of nuclear reactors.

Due to its characteristics of action: high mechanical (penetrating) effect, high temperature when hitting an object (pyrogenic effect), and consequences on people (radiological effect), depleted uranium began to be used by the NATO alliance in almost all armed conflicts after 1990 (Iraq, Republic of Srpska (Bosnia \& Herzegovina), Republic of Serbia, Libya, Somalia, Haiti, etc.). 
The following calibers of this type of ammunition are most often used for military purposes (Figure 1):

- $25 \mathrm{~mm}$ (BVP M2A2 and M3A3 Bradley - $85 \mathrm{~g}$ ),

- $30 \mathrm{~mm}$ (aircraft A-10 Thunderbolt II - $298 \mathrm{~g}$ ),

- 105 mm (tank Abrams M1, Leopard - from 2200 to $3700 \mathrm{~g}$ ), 120 mm (tank Abrams M1A2, Leclerc, Challenger - $5 \mathrm{~kg}$ ). (Serbian Armed Forces - General Staff, 2000, pp.25)

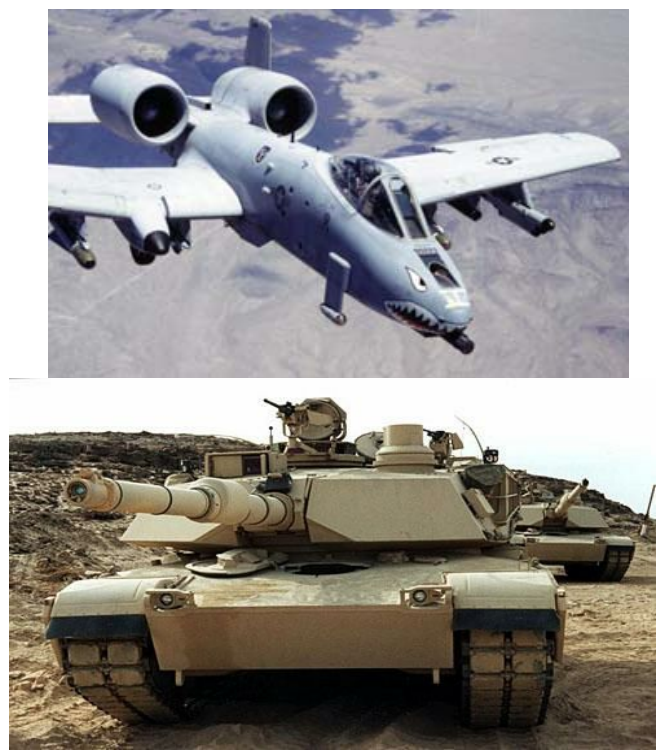

Figure 1 - Means for the application of DUA: A-10 Thunderbolt II aircraft and tank Abrams M1A2

Рисунок 1 - Средства для применения БОУ: авиация A-10 Thunderbolt II и танк Abrams M1A2

Слика 1 - Средства за примену МОУ: ваздухоплов A-10 Thunderbolt II и тенк Abrams M1A2

Certainly, the biggest problem for people when coming into contact with this type of illicit weapon (in addition to inhaling uranium oxide) is the delayed effect of DUA, and the consequences can be felt even after a few years.

\section{Reconnaissance of the areas contaminated with} depleted uranium ammunition

In the introduction, it was mentioned that the territory of the Republic of Serbia (without AP KiM) was targeted with DUA at 4 locations, namely: Pljačkovica (near Vranje), Borovac (near Bujanovac), Bratoselce, and Reljan (near Preševo), Figure 2. (Inđić, 2018, p.143) 


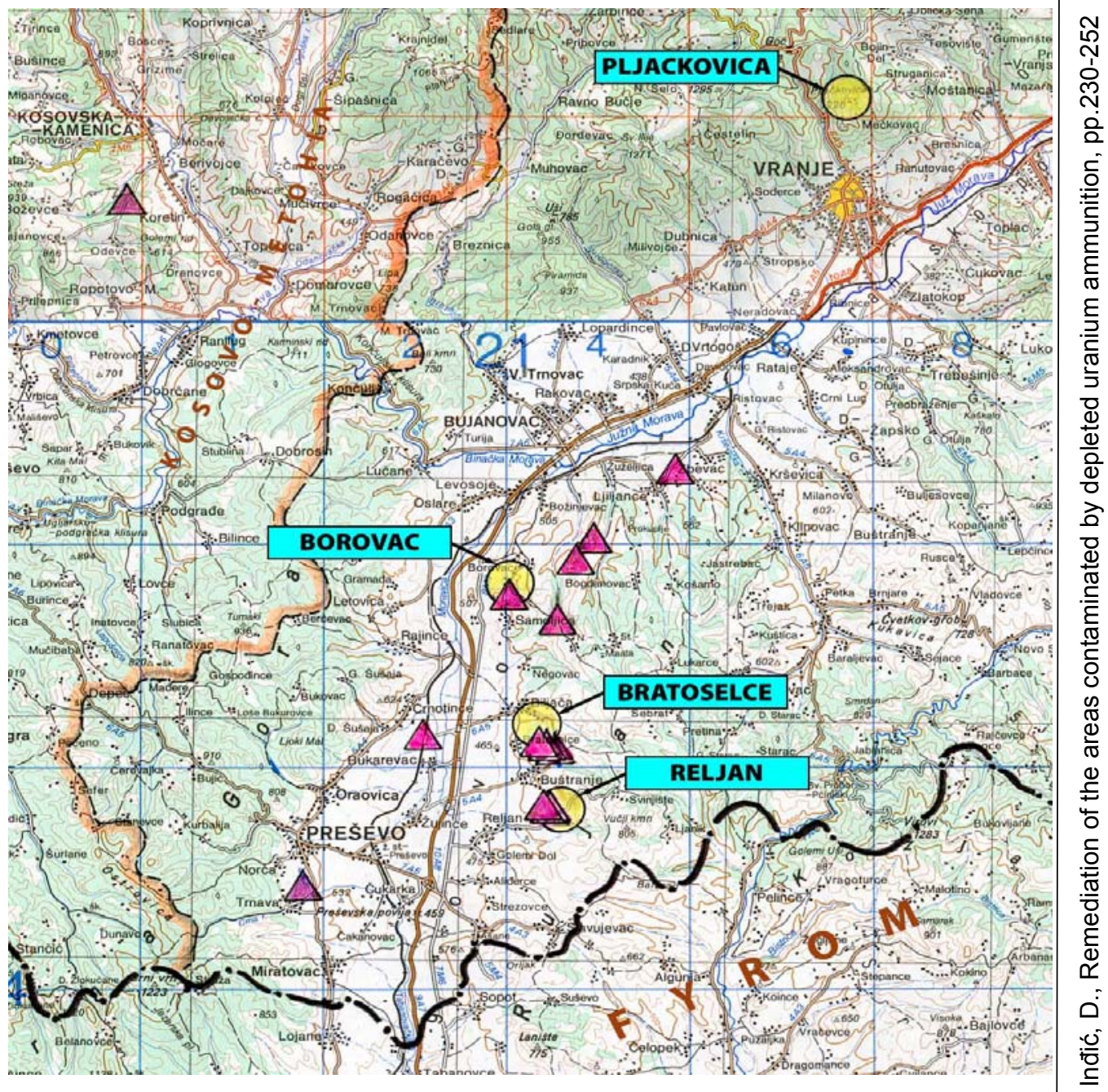

Figure 2 - Areas contaminated with depleted uranium ammunition in the area of R. Serbia (without AP Kosovo and Metohija) during the 1999 NATO aggression Рисунок 2 -_ Зоны, пораженные боеприпасами с обедненным ураном в районе P. Сербия (без АК Косово и Метохия) во время агрессии НАТО в 1999 г.

Слика 2 - Рејони контаминирани муницијом са осиромашеним уранијумом на подручју Р. Србије (без АП КиМ) током НАТО агресије 1999. године

Units of the ABHO (then the Yugoslav Army) performed a radiological survey of the mentioned areas and marked the contaminated ground for the purpose of later remediation of the consequences. On that occasion, the following was established at the above locations: 


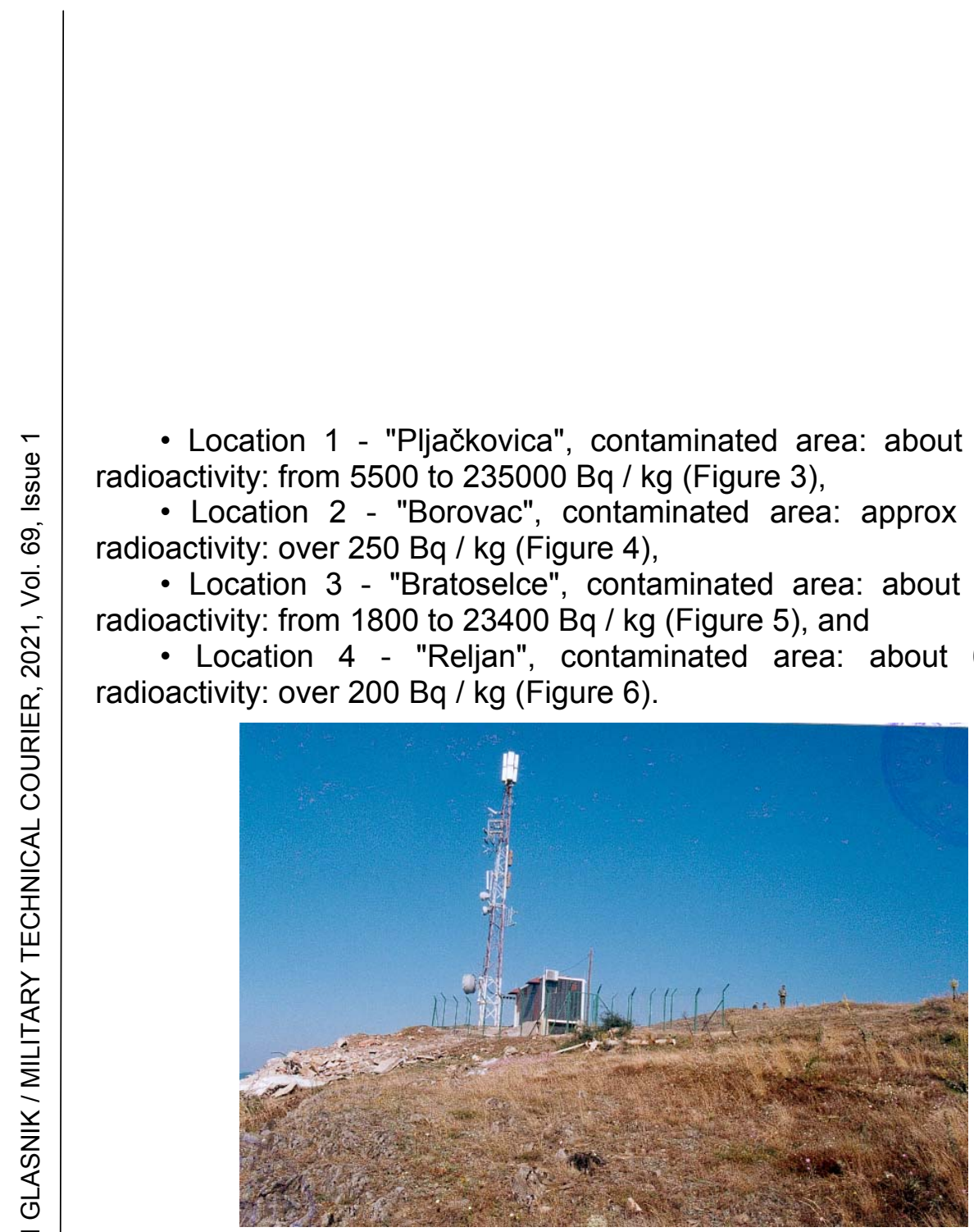

Figure 3 - Location 1 "Pljačkovica" Рисунок 3 - Локация 1 "Плячковица» Слика 3 - Локација 1 - „Пљачковица”

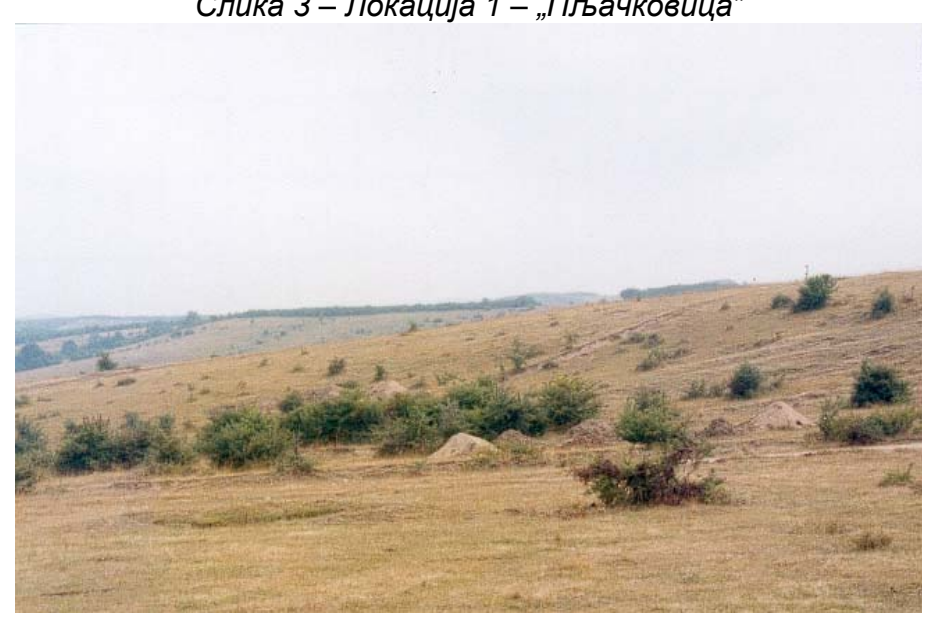

Figure 4 - Location 2 "Borovac"

Рисунок 4 - Локация 2 "Боровац»

Слика 4 - Локација 2 - „Боровац” 


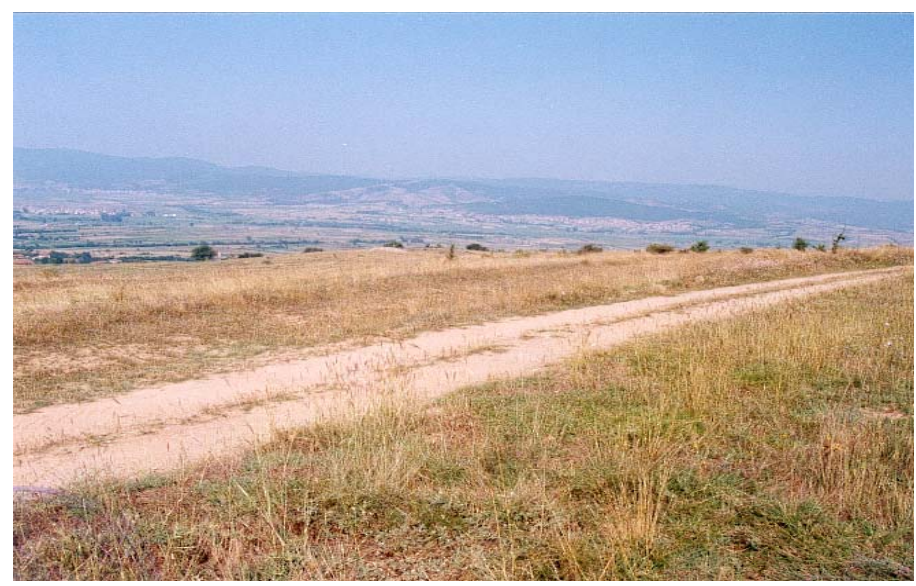

Figure 6 - Location 4 "Reljan" Рисунок 6 - Локация 4 «Релян» Слика 6 - Локација - 4 „Рељан”

The radiological reconnaissance was performed in accordance with the then valid rules and instructions of the $\mathrm{ABHO}$ units, and after the experiences gained on that occasion, the appropriate tactical actions of the $\mathrm{ABHO}$ units were changed and a new Instruction was issued.

For the radiological reconnaissance ( $R$ reconnaissance) of a location of DUA strikes, a group (reconnaissance body) is formed, consisting 
generally of: radiological reconnaissance scout and group commander at the same time; chemical reconnaissance scout; explosive technician; physician, and reconnaissance vehicle driver. The equipment for $R$ reconnaissance includes calibrated detectors of the type of radioactive contamination meter (RCM M-87), detector from the radiometric laboratory $\mathrm{M} 2$ (KOMO-TM), and general purpose radioactive radiation detector (GPRRD) or radiological detector (RD-M3). The detector probe window (KOMO-TM, RD-M3) must be open. RCM and GPRRD detectors must be protected by a plastic bag secured with an adhesive tape (rubber band). (Serbian Armed Forces - General Staff, 2014, pp.48-50)

For chemical reconnaissance ( $X$ reconnaissance), manual and semiautomatic chemical detectors should be provided, which in addition to formation detectors must also have indicator tubes (IT) for qualitative detection and quantitative determination of toxic gases produced as a product of explosives combustion $\left(\mathrm{CO}_{2}, \mathrm{CO}, \mathrm{NOx}, \mathrm{HCN}\right)$.

A shovel, a sampling set (KUM-1), plastic bags or sacks, metal containers with lids (so that they can hold a minimum of $1.5 \mathrm{~kg}$ of samples) and labels for marking samples are carried for sampling. A set of vehicle decontamination equipment (VDE) or a group decontamination device (GDD), and personal decontamination equipment (PDE M-3) are carried in case decontamination is needed. It is important to note that the physician must have medical supplies to provide for first aid for injuries from explosives and toxic chemicals (TC).

After receiving the order and preparing the equipment, the reconnaissance body puts the protective equipment in the preparatory mode and starts the reconnaissance. During the movement to the area of DUA action, the natural background of gamma radiation is occasionally controlled (from the vehicle). (Inđić, 2018, pp.141-144)

Upon arrival in the wider area of operation, the radiological reconnaissance scout turns on the KOMO-TM, while keeping the RCM M-87 in a pouch on a belt placed over the protective suit, and the chemical reconnaissance scout turns on the semi-automatic chemical detector (SACD) with a formation IT and prepares a hand-held chemical detector with a specific IT. About $300 \mathrm{~m}$ from the DUA strike site, the vehicle stops. Upon exiting the vehicle, the scouts put protective equipment in a protective position. The scout for $\mathrm{R}$ reconnaissance, at a distance of $10 \mathrm{~m}$ from the vehicle, controls the natural background of gamma radiation and the degree of soil contamination. The control is repeated in several places around the crater of the explosion, i.e. the place of DUA strike (in each place, 3 measurements are carried out and 
the mean value is taken), Figures 7 and 8 . (Serbian Armed Forces General Staff, 2014, pp.48-50)

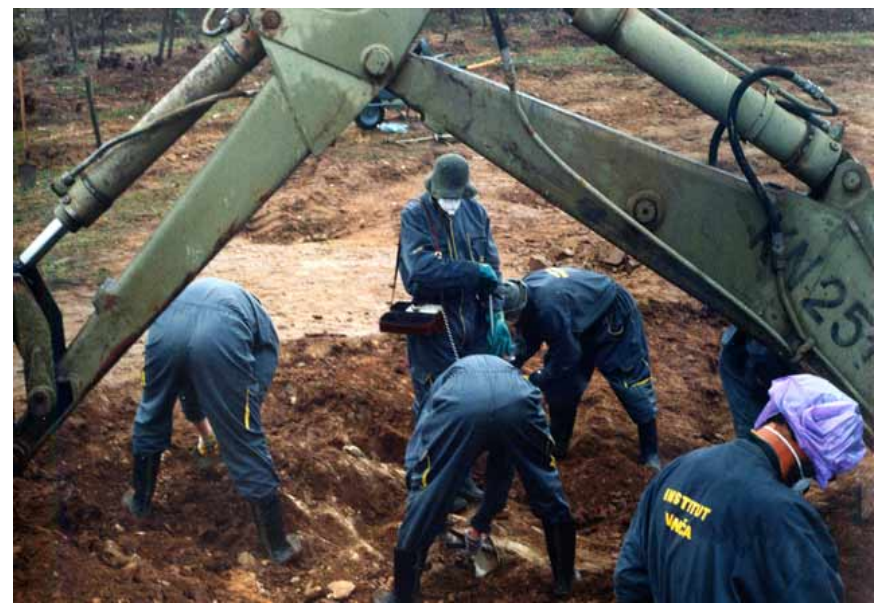

Figure 7 - Radiological reconnaissance of the place of DUA strike Рисунок 7 - Изображение радиологической разведки участки БОУ Слика 7 - Приказ радиолошког извиђања места дејства МОУ

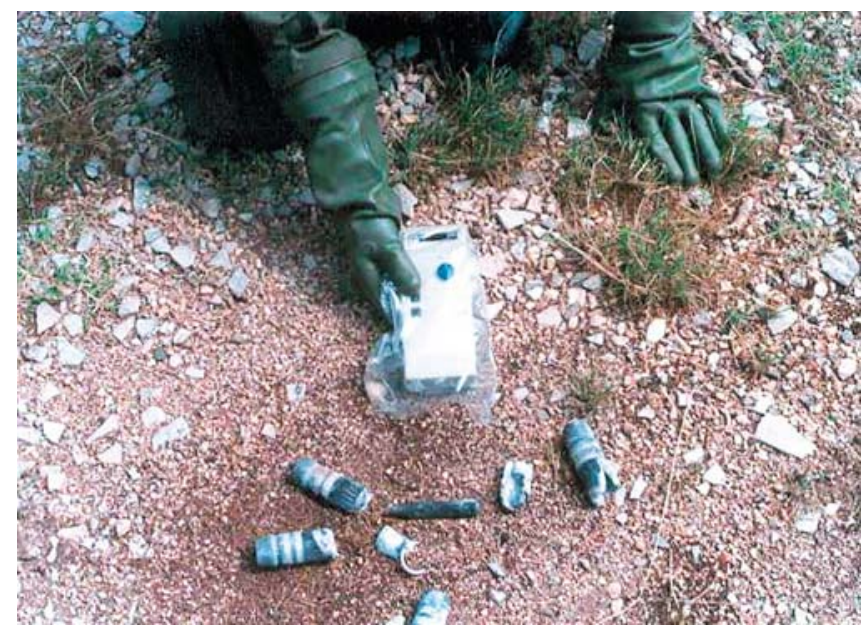

Figure 8 - Measurement of the radioactive contamination of DUA samples on the ground

Рисунок 8 - Измерение радиоактивного загрязнения образцов БОУ на почве Слика 8 - Мерење радиоактивне контаминације узорака МОУ на земљишту

During $\mathrm{R}$ reconnaissance, special attention must be paid to the altitude and the location where the measurements are performed, 
because the natural background of radioactive radiation can be 5 to 10 times higher than the average value for the territory of R. Serbia, which is about $0.1 \mu \mathrm{Gy} / \mathrm{h}$. After that, the degree of contamination is measured with the radiological device KOMO-TM (or RD-M3) with an open probe (the scout lowers the cable with the probe next to the foot, taking care not to touch the grass and other plants).

If there is a significant deviation from the typical natural background (deviation values greater than $0.5 \mu \mathrm{Gy} / \mathrm{h}$ ), from that point the scout for $\mathrm{X}$ reconnaissance takes soil samples as follows:

- first, the layer of vegetation is removed from the surface of $1 \mathrm{~m}^{2}$ with an ax and thus the first sample is formed;

- another sample is taken from the same surface by removing soil about $2 \mathrm{~cm}$ deep.

The mass of each sample must be up to $1.5 \mathrm{~kg}$, and soil samples are taken from the place where the greatest contamination was determined ( 3 to 5 places). Air sampling is taken with a special device (chemical detector) and filtering through a cellulose-asbestos filter with a minimum of $100 \mathrm{~m}^{3}$ of air. The area in which the increased degree of radioactive contamination was determined is marked with a set of CSM. The value of radiation taken as the limit of the contamination area is 0.5 $\mu \mathrm{Gy} / \mathrm{h}$. (Serbian Armed Forces - General Staff, 2014, pp.48-50)

The scout for $X$ reconnaissance controls the presence of TC with the help of SACD, and determines a possible presence and concentration of other toxic substances with a hand-held chemical detector (Figure 9).

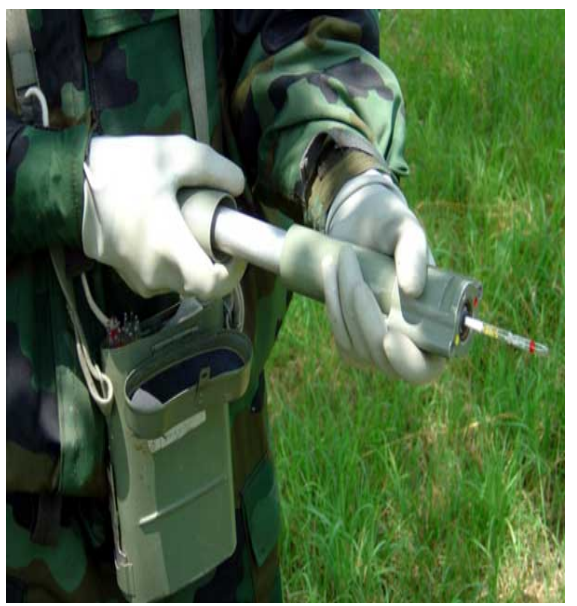

Figure 9 - Method of detection of toxic chemicals Рисунок 9 - Метод обнаружения токсичных химикатов Слика 9 - Начин детекције отровних хемијских супстанци 
After the $\mathrm{R}$ and $\mathrm{H}$ reconnaissance of the areas contaminated with DUA, it was possible to eliminate the consequences with a focus on radiological decontamination.

Two important facts must be stated here:

- first, during the $R$ and $X$ reconnaissance, the DUA effects on the flora and fauna in the contaminated areas were not considered, which is of exceptional importance from the aspect of complete protection (humans, flora and fauna, as well as the environment), and

- second, several years passed from the moment of the reconnaissance of the areas contaminated with DUA to the moment of the remediation or radiological decontamination of the area (3 to 8 years).

\section{Decontamination of the areas contaminated with depleted uranium ammunition}

Starting in 2001, with the adoption of the then unique algorithm of work on decontamination of areas contaminated with depleted uranium ammunition, the remediation work began as follows:

- Cape "Arza" in R. Montenegro, remediated in 2001 and 2002,

- location "Bratoselce", remediated in 2002 and 2003,

- location "Pljačkovica", remediated in 2004,

- two locations in the area of "Borovac", remediated in 2005, and

- location "Reljan", remediated in 2006 and 2007.

The manner in which the remediation i.e. decontamination of the areas contaminated with DUA was performed will be shown on the example of the "Bratoselce" area. The Proposal of CGS YA to the President of the State and the Prime Minister of the Republic of Serbia for the permanent solution of the remediation of contaminated areas (at the beginning of 2002) preceded the creation of the Contaminated Soil Remediation Project at the "Bratoselce" location and its submission to the then Federal Government for adoption.

After the adoption of the project, the realization started with the participation of units and institutions of the then $A S$ and $M N$ and members of the Institute of Nuclear Sciences "Vinca" (INS "Vinca"). The project was managed by an expert team: three members from AS and MN and three members from the INS "Vinca". The engagement in the implementation of this activity was as follows:

- ABHO SA Management (project implementation management);

- ABHO SA units (performing R decontamination); 
- MMA (medical supervision and examination of personnel);

- Engineering units (communication and $\mathrm{R}$ decontamination assistance);

- other AS and MN units (security and logistics).

The dosimetric control of the contaminated area began in midSeptember 2002 with the aim of:

- finding depleted uranium ammunition,

- removal of DUA and contaminated soil and their disposal in the special facilities of INS "Vinča",

- removal of fences and danger signs and return of land to its original purpose.

The efficiency of detection and decontamination was influenced by the following factors:

- knowledge of microlocation (traces of strikes after three years were not noticeable);

- soil characteristics - increased concentration of natural uranium and geological composition made it difficult to detect and decontaminate (projectiles were detected at depths of 50 to $100 \mathrm{~cm}$ );

- characteristics of the measuring equipment - it was mainly domestic equipment, because the procurement of foreign equipment was very difficult (as a whole, domestic equipment showed satisfactory results);

- detection methods - radiological search of the surface part by sectors (very difficult due to low surface contamination), removal of the surface layer and re-detection and finally digging of characteristic sections to a depth of $1 \mathrm{~m}$.

The decontamination works began with the arrangement and preparation of the area of works and the organization of security. The following were engaged in the realization of the task: the working team for work on decontamination (professional members of $\mathrm{ABHO}$ and the Military Academy, as well as the experts from the INS "Vinca") and the unit for security and logistics (from the ABHO unit then AS and MN).

The working team worked in three groups:

- clearing group,

- dosimetric examination group, and

- penetrator removal group. 
With this work organization, a probability of finding contamination was higher than $90 \%$ and a possibility of "failure" in finding and extracting depleted uranium projectiles was almost certainly ruled out.

For more efficient work on the decontamination of DUA contaminated areas, the members of engineering units also participated with engineering machines in field preparation (construction of access communications) and $\mathrm{R}$ decontamination (removal of the upper layer of contaminated soil), Figure 10.

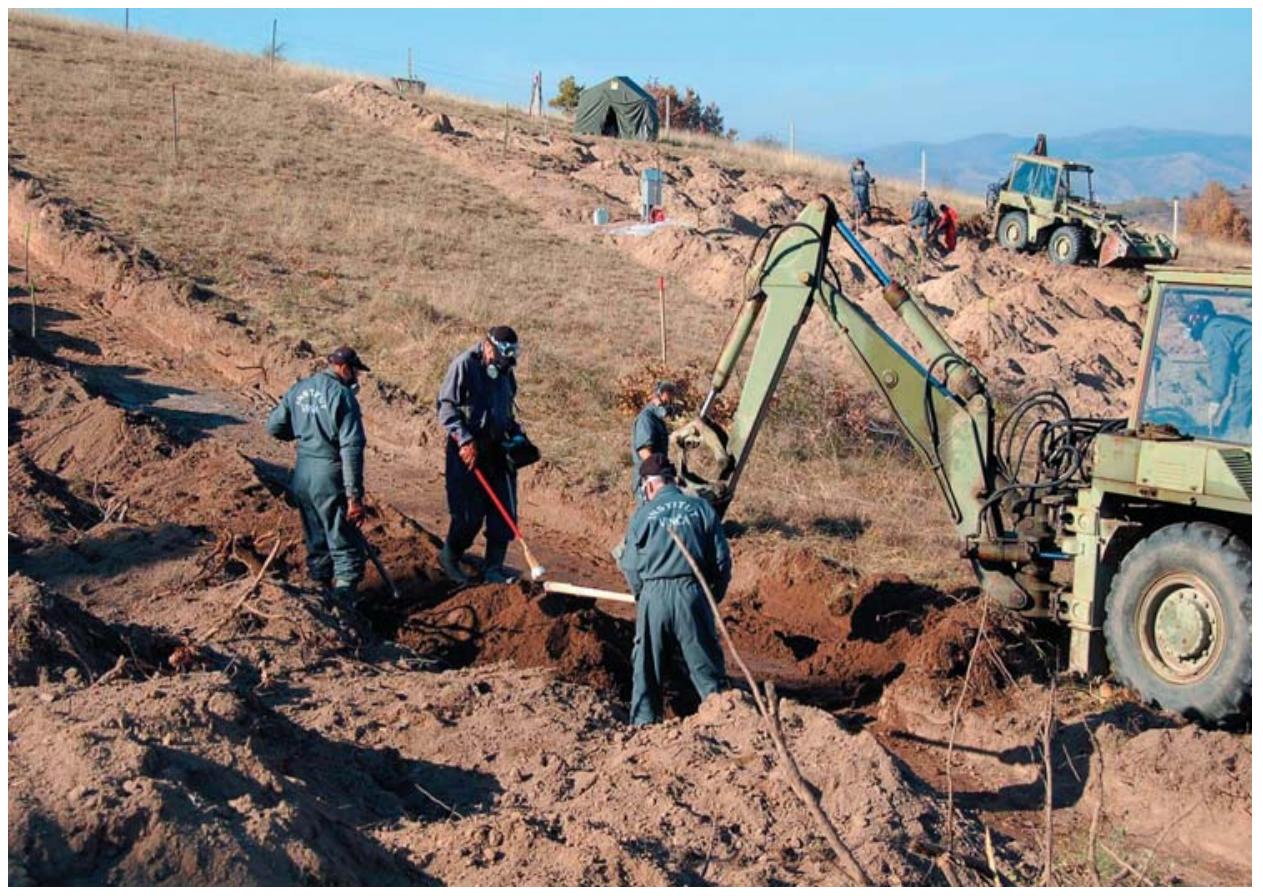

Figure 10 - Soil decontamination using engineering machines Рисунок 10 - Обеззараживание почвы инженерными машинами Слика 10 - Деконтаминација земљишта употребом инжињеријских машина

Due to a large volume of work and unfavorable weather conditions, the works had to be stopped at the end of 2002 and continued in the spring of 2003 (Figure 11), when the area of the village of Bratoselce was completely decontaminated from depleted uranium. 


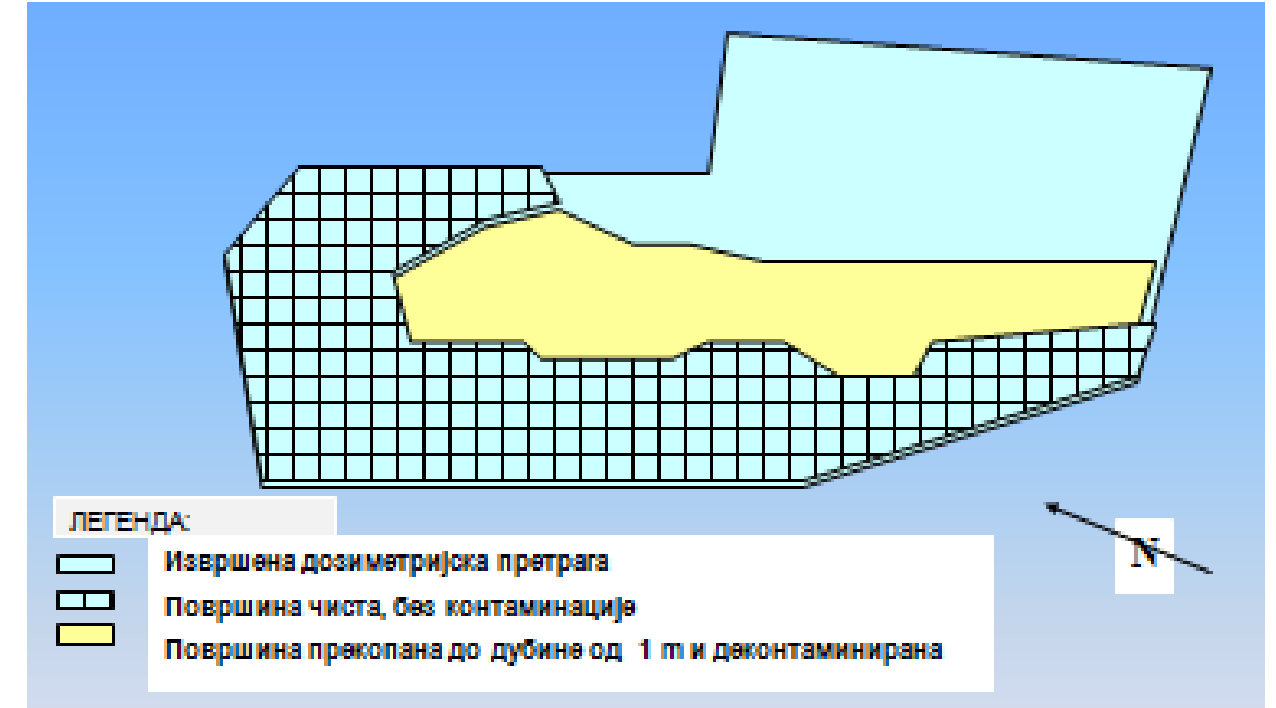

CAPTION:

Dosimetry applied

Clean surface, without contamination

Surface layer removed up to the depth of $1 \mathrm{~m}$ and decontaminated

ПОЯСНЕНИЕ:

$\square$ Произведены дозиметрические исследования

$\square$ Участок чист, контаминации нет

Участок был раскопан и обезврежен до 1 м вглубь

Figure 11 - Scheme of the contaminated land in the village of Bratoselce Рисунок 11 - Схема загрязненной почвы в деревне Братоселце

Слика 11 - Шема контаминираног земљишта у селу Братоселце

The results and experiences in the remediation of the consequences of the DUA use in the area of the village of Bratoselce can be presented as follows:

- complete decontamination of the contaminated soil (area of 54 ares) was performed;

- over 320 penetrators and more than 300 shells from depleted uranium projectiles were found (the largest number at a depth of 50 to $100 \mathrm{~cm}$ );

- about three tons of contaminated soil were collected; 
- parts of DUA and contaminated soil were deposited in the special warehouse of the INS "Vinča";

- Members of the army achieved high competency by applying the experience from the decontamination of Cape Arza in R. Montenegro;

- measuring instruments of domestic production were used (KOMOTM, RCM, SACD, etc.);

- due to the acquired experiences and characteristics of the soil, the following tasks were realized much faster (remediation of the Pljačkovica region near Vranje, Borovac near Bujanovac and the Reljan region near Preševo).

After performing gamma spectrometric analyzes on 25 samples taken from the area of the village of Bratoselce, it was proven that the site was completely decontaminated, i.e. the effects of depleted uranium were remediated according to the requirements of the construction project.

Once again, it must be pointed out that more than three years passed from the moment of DUA strikes to the decontamination of the area, which could have resulted in the pollution of the flora and fauna as well as the environment at the said location.

\section{Conclusion}

The use of depleted uranium ammunition by the NATO countries has led to serious consequences for people and the environment in the countries targeted by this type of prohibited weapon. The goal of using this type of weapon, in addition to the military one, is certainly to solve the problem of radioactive waste in the NATO countries that possess it, especially when the half-life of uranium (about 4.5 billion years) is taken into account.

Even after several decades of the application of DUA in the area of the Republic of Serbia, conclusions are drawn about the scope and severity of the consequences of its application. To that end, in 2018, the Assembly of the Republic of Serbia formed a Commission to investigate the consequences of the NATO bombing in 1999 on the health of citizens and the environment (Čekerevac, 2018). The task of the commission, among other things, is to determine the negative effects of toxic chemical substances in the destroyed facilities of the process industry ("Petrohemija" and "Azotara" Pancevo, facilities of the oil industry of 
Serbia, facilities of military industry in Baric, Lucani, Kragujevac and many others) south R. Serbia, etc. (Inđić, 2012, pp.288-307)

Faced with the problem of a new type of weapon, the units of the Serbian Army (YA, AS and MN) decisively and bravely chose the optimal method of implementation, first radiological reconnaissance, and later radiological decontamination of the areas contaminated with depleted uranium. The competent institutions of the Republic of Serbia, such as the INS "Vinča", the MMA and others, provided them with great help in the realization of the mentioned tasks.

Certain problems that arose during the implementation of the remediation of the areas contaminated with DUA were:

- delayed effect of DUA (radiological decontamination was realized much later than the use of DUA);

- soil characteristics - increased concentration of natural uranium and geological composition made detection and decontamination difficult (projectiles were detected at depths over $50 \mathrm{~cm}$ );

- characteristics of the measuring equipment - mainly domestic equipment was used (which showed good results);

- detection methods - radiological search of the surface area by sectors (very difficult due to low surface contamination);

- work for a longer period of time with protective equipment in a protective position (so radiological decontamination was mostly realized in late autumn or early spring);

- insufficient experience in working on remediation of DUA consequences, etc.

Despite the mentioned problems, the units of the army, together with competent state institutions, successfully realized the remediation of the areas contaminated with depleted uranium on the entire territory of the Republic of Serbia (without the autonomous province of Kosovo and Metohija). It must be especially emphasized that the Army of Serbia (YA, AS and MN) was the first in the world to completely perform radiological decontamination of areas contaminated with depleted uranium ammunition, without the help of other countries.

The experience gained at that time served for further improvement of tactical actions and procedures of $\mathrm{ABH}$ service units in eliminating the consequences of the use of radiological weapons, as well as for training in eliminating the consequences of nuclear and chemical accidents in peacetime. (Inđić et al, 2015, pp.215-239) 


\section{References}

Arevalo, R.Jr., McDonough, W.F. \& Luong, M. 2009. The K/U ratio of the silicate Earth: Insights into mantle composition, structure and thermal evolution. Earth and Planetary Science Letters, 278(3-4), pp.361-369. Available at: https://doi.org/10.1016/j.epsl.2008.12.023.

Binder, H.H. 1999. Lexikon der chemischen Elemente. Stuttgart; Leipzig: Verlag (in German). ISBN: 978-3-7776-0736-8.

Brauer, G. 1975. Handbuch der präparativen anorganischen Chemie. Stuttgart: Enke (in German). ISBN: 3432878133, 9783432878133.

Čekerevac, M. 2018. Imenovana Komisija za ispitivanje posledica NATO bombardovanja. Politika, 25 May [online]. Available at: http://www.politika.rs/sr/clanak/404403/Imenovana-Komisija-za-ispitivanjeposledica-NATO-bombardovanja (in Serbian) [Accessed: 10 October 2020].

Đurić, G.D. \& Popović, D.Lj. 2000. Uranium in the environment. Hemijska industrija, 54(2), pp.50-52 [online]. Available at. https://scindeksclanci.ceon.rs/data/pdf/0367-598X/2000/0367-598X0002050D.pdf (in Serbian) [Accessed: 10 October 2020].

Holleman, A.F., Wiberg, E. \& Wiberg, N. 2007. Lehrbuch der Anorganischen Chemie. Berlin: de Gruyter (in German). ISBN: 978-3-11-017770-1.

Inđić, D. 2012. The place of NBC service units in protection against chemical accidents. Vojno delo, 64(1), pp.288-307 (in Serbian).

Inđić, D.R., Terzić, M.R., Žigić, S.V. \& Rutić, S.Z. 2015. Engagement of the Serbian Army in helping civilians in the event of nuclear and chemical accidents. Vojnotehnički glasnik/Military Technical Courier, 63(3), pp.215-239 (in Serbian). Available at: https://doi.org/10.5937/vojtehg63-6923.

Inđić, D. 2018. Taktika jedinica ABH službe - udžbenik. Belgrade: University of defence in Belgrade - Military academy (in Serbian).

Inđić, D.R. \& Filipović, V.R. 2018. Model snaga ABH službe za otklanjanje posledica primene radiološkog oružja u terorističke svrhe. Vojno delo, 70(4), pp.259-281 (in Serbian). Available at: https://doi.org/10.5937/vojdelo1804259I.

Meija, J., Coplen, T.B., Berglund, M., Brand, W.A., De Bièvre, P., Gröning, M., Holden, N.E., Irrgeher, J., Loss, R.D., Walczyk, T. \& Prohaska, T. 2016. Atomic weights of the elements 2013 (IUPAC Technical Report). Pure and Applied Chemistry, 88(3), pp.265-291. Available at: https://doi.org/10.1515/pac-2015-0305.

Rajković, M.B. 2001. Depleted uranium I: Natural uranium, radioactivity and legal regulation. Hemijska industrija, 55(4), pp.167-182 [online]. Available at. https://scindeks-clanci.ceon.rs/data/pdf/0367-598X/2001/0367-

598X0104167R.pdf (in Serbian) [Accessed: 10 October 2020].

-Serbian Armed Forces - General Staff. 2000. Uputstvo za protivnuklearno obezbeđenje Vojske Jugoslavije u uslovima upotrebe municije od osiromašenog uranijuma (privremeno). Belgrade: Serbian Armed Forces - General Staff. Directorate for NCBD (in Serbian).

-Serbian Armed Forces - General Staff. 2014. Uputstvo za RHB izviđanje $i$ dozimetrijsku kontrolu. Belgrade: Serbian Armed Forces - General Staff (in Serbian). 


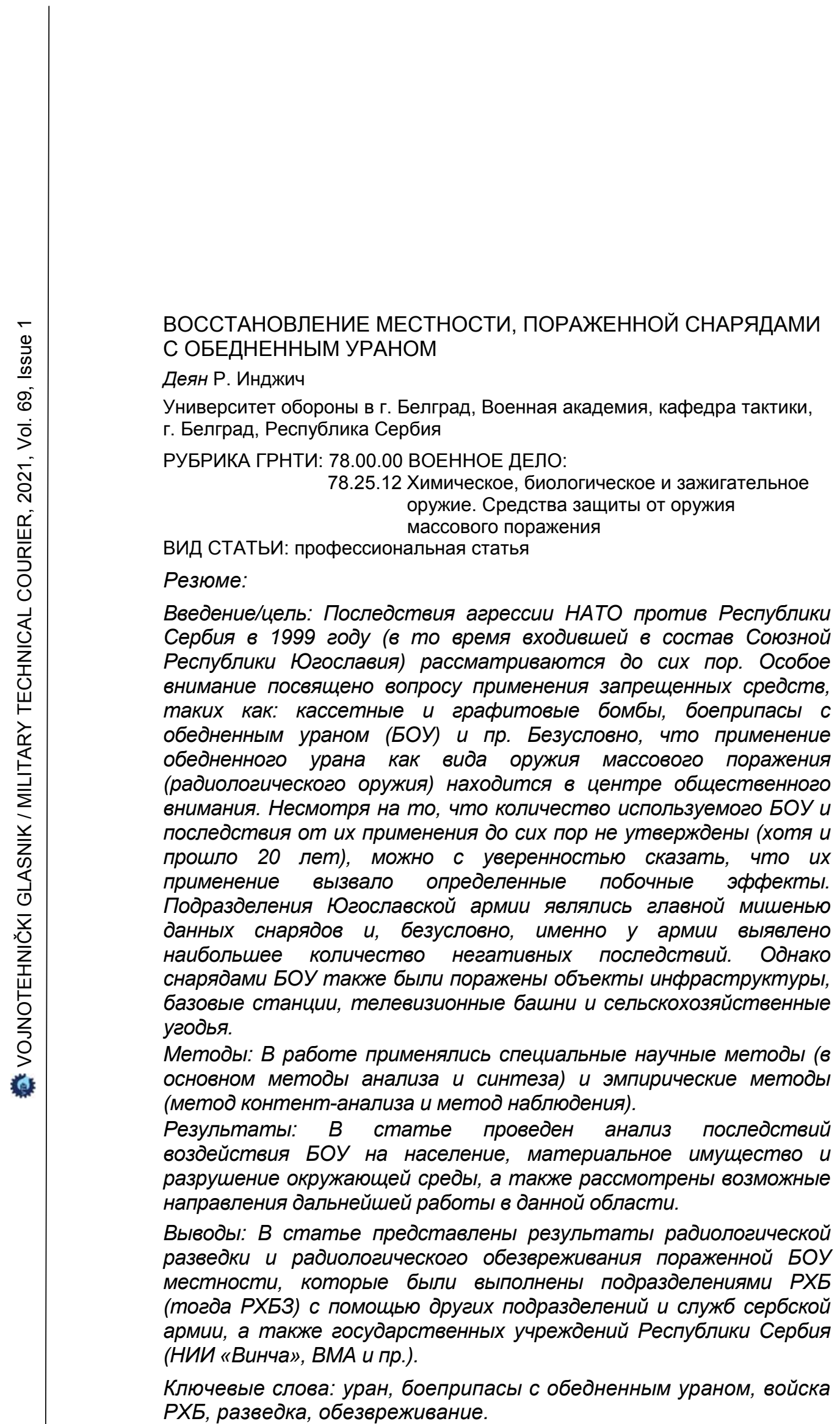


САНАЦИЈА ПОДРУЧЈА КОНТАМИНИРАНИХ МУНИЦИЈОМ СА ОСИРОМАШЕНИМ УРАНИЈУМОМ

Дејан Р. Инђић

Универзитет одбране у Београду, Војна академија, Катедра тактике, Београд, Република Србија

ОБЛАСТ: хемијске технологије

ВРСТА ЧЛАНКА: стручни рад

Сажетак:

Увод/циљ: Последице НАТО агресије на Републику Србију (тада у саставу СР Југославије) 1999. године још увек се разматрају, посебно са аспекта употребе недозвољених средстава, попут касетних и графотних бомби, муниције са осиромашеним уранијумом (МОУ) и др. Свакако да је употреба осиромашеног уранијума, као једне врсте оружја за масовно уништавање (радиолошко оружје), највише у фокусу интересовања јавности. Количина коришћене МОУ и последице њене употребе још увек (и после 20 година) нису у потпуности доказане, али се са сигурношћу може рећи да је она проузроковала одређене нежељене ефекте. Тадашње јединице Војске Југославије биле су главни циљ дејства овом врстом муниције, па су претрпеле и највеће последице. Међутим, дејством МОУ гађани су и објекти инсрраструктуре, базне станице, телевизијски предајници и пољопривредно земљиите.

Memode: У раду су коришћене посебне научне методе (тежишно метода анализе и синтезе) и емпиријске методе (метода анализе садржаја и метода посматрања).

Резултати: Сагледане су последице дејства МОУ на људе, материјална добра и деградирање животне средине, као и правци даљег рада у овој области.

Закључак: Приказани су резултати радиолошког извиђања и радиолошке деконтаминације подручја контаминираних МОУ, које су реализовале јединице АБХ службе (maда рода АБХО) уз помоћ осталих родова и служби Војске Србије, као и институција Републике Србије (ИНН „Винча”, ВМА и др.).

Кључне речи: уранијум, муниција са осиромашеним уранијумом, АБХ служба, извиђање, деконтаминација.

Paper received on / Дата получения работы / Датум пријема чланка: 14.10.2020. Manuscript corrections submitted on / Дата получения исправленной версии работы / Датум достављања исправки рукописа: 01.12.2020.

Paper accepted for publishing on / Дата окончательного согласования работы / Датум коначног прихватања чланка за објављивање: 03.12.2020. 
(c) 2021 The Author. Published by Vojnotehnički glasnik / Military Technical Courier (www.vtg.mod.gov.rs, втг.мо.упр.срб). This article is an open access article distributed under the terms and conditions of the Creative Commons Attribution license (http://creativecommons.org/licenses/by/3.0/rs/).

(c) 2021 Автор. Опубликовано в «Военно-технический вестник / Vojnotehnički glasnik / Military Technical Courier» (www.vtg.mod.gov.rs, втг.мо.упр.срб). Данная статья в открытом доступе и распространяется в соответствии с лицензией «Creative Commons» (http://creativecommons.org/licenses/by/3.0/rs/).

(C) 2021 Аутор. Објавио Војнотехнички гласник / Vojnotehnički glasnik / Military Technical Courier (www.vtg.mod.gov.rs, втг.мо.упр.срб). Ово је чланак отвореног приступа и дистрибуира се у складу са Creative Commons licencom (http://creativecommons.org/licenses/by/3.0/rs/). 